\title{
Corporate Governance and Accounting Performance:
}

\section{A Balanced Scorecard Approach}

\author{
Mona A. Elbannan ${ }^{1}$ \& Mohamed A. Elbannan ${ }^{1,2}$ \\ ${ }^{1}$ School of Business, American University in Cairo, Cairo, Egypt \\ ${ }^{2}$ Faculty of Commerce, Cairo University, Giza, Egypt \\ Correspondence: Mona Elbannan, School of Business, American University in Cairo, PO Box 74, New Cairo, Cairo \\ 11835, Egypt. Tel: 20-2-2615-2709. E-mail: monaelbannan@aucegypt.edu
}

Received: March 7, 2014

Accepted: March 18, 2014

Online Published: March 20, 2014

doi:10.5430/afr.v3n2p60

URL: http://dx.doi.org/10.5430/afr.v3n2p60

\begin{abstract}
This paper is motivated by the financial reform plan implemented in the Egyptian banking sector to enforce good corporate governance practices and improve performance. The study examines the association between governance quality and performance by estimating OLS regression models to test this relation. We measure governance as a multidimensional composite index comprised of board and ownership structure characteristics, while bank performance is measured using the Balanced Scorecard approach including financial and non-financial measures. Empirical evidence shows that governance has positive and significant impact on Egyptian bank performance. In particular, for the board structure, evidence shows that more executive directors on the board will enhance employee's productivity. We find that board size is an insignificant determinant for bank performance; however, small board size is a significant determinant for better customer-related performance and improved employee productivity. $\mathrm{CEO} / \mathrm{Chairman}$ duality is unrelated to bank performance, financial and non-financial performance. As for ownership structure, direct foreign investment in Egyptian banks should be encouraged, as there is evidence that foreign ownership has favorable impact on bank performance especially on employee productivity. Ownership concentration adversely affects bank performance index, and has unfavorable effect on employee productivity. Finally, institutional ownership is a marginal determinant of employee productivity.
\end{abstract}

Keywords: Corporate governance, Banking, Balanced scorecard, Egypt

\section{Introduction}

Banks represent the nerve of any economy and the backbone of the financial services sector, thus they have strong effect on the economic development and prosperity.

The Basel Committee on Banking Supervision (BCBS) aims to improve the quality of banking supervision worldwide. In addition to Basel I and II requirements regarding bank capital adequacy, disclosure and transparency, and empowering supervisory authorities, BCBS formulates the principles for good corporate governance in banks to enhance bank stability and soundness worldwide (Basel 2006).

In order to comply with requirements of the Basel Accords and enhance banks performance, the government launched its comprehensive financial sector reform program in 2004 to be implemented over the period from 2005-2008. The reform plan includes privatization and consolidation of the banking sector, restructuring of state-owned banks, solving non-performing loans problems, and enhancing the Central Bank of Egypt (CBE) banking supervision (C.B.E., 2007, p.12).

In line with the 2004 banking system reform plan, a series of legislative reforms starting with the promulgation of Banking Law No. 88 of the year 2003 has taken place. The law incorporates the guidelines of the Basel Accords and includes most of the five corporate governance principles determined by the Organization of Economic Cooperation and Development (OECD), and was declared a major step forward into facing global banking competition and driving financial growth in Egypt.

Regarding corporate governance principles, the law sets the rules of disclosure, reserve ratios, banks ownership structure, and responsibilities of board of directors. The structure and responsibilities of board of directors are placed at the core of a corporate governance framework for banks, as the bank board of directors has a very sensitive role 
suggested by (BCBS). The major reforms in Egypt include the issuance of the 2005 corporate governance code.

This research raises the question of whether reforming the Egyptian banking sector and implementing good bank governance principles give its fruits and enhance banks' performance. Thus this research aims is to examine the relation between corporate governance and performance in the context of the Egyptian banking sector as bank performance is a function of governance quality.

We estimate OLS regression models to test these relations. The sample consists of Egyptian banks whose financial information is available. We measure governance as a multidimensional self-constructed composite index comprised of board structure characteristics and ownership structure characteristics. We measure performance also as a multidimensional composite index comprised of Balanced Scorecard dimensions.

To the best of our knowledge, this is the first study to measure governance in the Egyptian banking sector using a multidimensional governance index comprised of six governance indicators: board size, board composition, leadership structure (duality), foreign ownership, institutional ownership, and ownership concentration. We use factor analysis to group the six variables into a single governance score. Moreover, we measure the Egyptian bank performance using the Balanced Scorecard (BSC) by constructing a multidimensional performance index consisting of financial and non-financial measures to cover four dimensions; financial, customer, internal processes, and learning \& growth. Again, we use factor analysis to create a performance index comprising the four perspectives of the BSC.

The results of this study should therefore be of interest to regulators, banking sector participants, economists, and other parties. Economic reforms in emerging markets such as Egypt should be guided by continuous research and data analysis.

This research is organized as follows. Section 2 reviews the prior studies on the relation between corporate governance and firm performance and develops the hypothesis of the study. Section 3 describes the sample, and defines the variables and model specification. Section 4 discusses the study empirical results and section 5 concludes.

\section{Literature Review and Hypothesis development}

\subsection{Relation between corporate governance and Bank performance}

Corporate governance is defined in most studies from either an investor protection or functional perspective. BCBS adopts the functional view, where it defines CG as involving "the manner in which the business and affairs of banks are governed by their boards of directors and senior management, which affects how they set corporate objectives; operate the bank's business on a day-to-day basis; meet the obligation of accountability to their shareholders and take into account the interests of other recognized stakeholders; align corporate activities and behavior with the expectation that banks will operate in a safe and sound manner, and in compliance with applicable laws and regulations; and protect the interests of depositor" (Basel, 2006).

The literature suggests corporate governance mechanisms, classified into external control mechanisms, such as stock market, market for corporate control (takeovers), and competition in product markets (Macey and O'Hara, 2003), and internal control mechanisms, such as board of directors (Fama and Jensen, 1983), monitoring by block-holders, compensation contracts, and managerial equity investment (Adams and Mehran, 2005; and Macey and O'Hara, 2003).

\subsubsection{Board structure and bank performance}

Many studies examine the factors affecting the board ability to function effectively. They test the relationship between the board structure and the firm performance, where the board structure includes the size of the board, board composition (presence of dependent and independent directors), board leadership structure (CEO-Chairman duality) where the position of CEO and chairman is held by one person. The literature on the relation between bank board size and performance suggests a significant relation (Zemzem, and Kacem, 2014). Many studies argue that large boards have positive effect on bank performance e.g., Subrahmanyam et al. (1997), Andres and Vallelado (2008), and Belkhir (2009), and banking firms have larger boards than its non-bank counterparts (Booth et al., 2002). Adams and Mehran (2005) report an average board size of 18 directors (Note 1). Andres and Vallelado (2008) argue that large boards create more value for banks, and document that the mean and median sizes of the board are 15.78 and 16 directors, respectively (Note 2).

There are three reasons mentioned in the literature to justify the large size for bank board: the board size is positively related to firm size (Linck et al., 2008). the increase in mergers and acquisitions activity and complicated hierarchical 
structure of the BHC and complex organizational structure of banks (Adams and Mehran, 2005). Studies testing the effect of board independence show that bank performance is not improved by increasing the proportion of independent directors in banks and no significant relationship between presence of outsiders and bank performance (Pi and Timme, 1993; and Staikouras et al., 2007). However, other studies suggest that larger banks have larger board size composed of more independent directors (e.g. Subrahmanyam et al., 1997; and Belkhir, 2009). Staikouras et al. (2007) report that percentage of outside directors on banks boards ranges from a minimum of 16.67 percent to a maximum of 90.00 percent, with a mean of 64.40 percent in a sample of 58 large European banks from 2002-2004. Andres and Vallelado (2008) record the percentage of outsiders to be 79 percent of directors, but when reaching a high proportion over the total board, Q starts to diminish indicating that the advisory role and the information provided by inside directors are important to perform efficiently.

The dual structure of board leadership, where the CEO and Chairman of the board positions being occupied by the same person, could impede the flow of information to other directors because it enables the CEO to control the information flow to other board members resulting in less effective monitoring (Jensen, 1993). Banks Leadership structure and performance relationship is examined empirically, for example, Booth et al. (2002) argue that $\mathrm{CEO} /$ Chair duality is less likely when insider stock ownership increases, and it is of less importance in reducing agency conflicts in regulated industries as regulations can substitute these monitoring mechanisms. Pi and Timme (1993) report a negative relationship between bank performance and duality due to the increase in the agency conflicts between owner and management. In contrast, Brickley et al. (1997) argue that there is no negative relationship between the $\mathrm{CEO}-$ Chairman duality and different measures of performance, and suggest that combining the titles of the CEO and Chairman in one person is efficient and achieve shareholders' interests.

\subsubsection{Ownership structure and bank performance}

Regarding the literature on the effect of ownership structure on performance includes the ownership concentration and identity effects.

The benefits and costs of ownership concentration have been widely discussed since Berle and Means (1933) argue that widely dispersed ownership reduces the effective power of shareholders to control the management of the firm. In the same context, Levine (2004) argues that concentrated ownership is a governance mechanism that prevent managers from deviating from shareholder interests as large shareholders have incentives to acquire information and monitor managers than small shareholders.

The literature on the ownership structure and corporate control ends up with two divergent views. On one hand, some scholars support Berle and Means (1933) view and argue that the concentration of ownership is more effective and enhances corporate control. Shleifer and Vishny (1986) argue that shareholders are better in monitoring management, especially with weak or limited shareholders protection rights, and they also play an important role in takeovers. Also, Shehzad et al. (2010) find that concentrated ownership significantly reduces a bank's non-performing loans ratio, and improves the capital adequacy ratio conditional on the extent of shareholder protection rights. Similarly, Iannotta et al. (2007) find that higher ownership concentration is associated with better loan quality, lower asset risk and lower insolvency risk in European banking industry.

On the other hand, others suggest that ownership concentration is of less importance in banks. It may even have negative effect because, for example, large shareholders may have different interests from minority shareholders and seek to achieve their own interests (Gomes and Novaes, 2005), exert expropriation threat (Burkart et al., 1997), and take higher risk as they have strong power and incentives to increase risk (Laeven and Levine, 2009). Further, Pi and Timme (1993) suggest that cost efficiency and return on assets are unrelated to institutional and large blockholders ownership.

Many studies examine the relationship between the nature or identity of bank owners and bank performance. There is consensus in the literature that government-owned banks achieve less profitability compared with other types of banks (for example, Berger et al., 2005). The reasons behind the poor performance of government owned banks are for example, the poor loan quality (non-performing loans) and high insolvency risk (Iannotta et al., 2007; Berger et al., 2005), lower net interest margin and higher overhead costs (Micco et al., 2004), and operating inefficiency and high operating costs (Kwan, 2004). In contrast, the foreign ownership is positively and significantly associated with different bank performance measures (Choi and Hassan, 2005). In developing countries, foreign banks tend to be characterized by high levels of profitability due to low overhead costs (Micco et al., 2004).

Regarding the institutional ownership, Elyasiani and Jia (2008) find that it enhances BHCs performance; however, this relationship is weaker in BHCs than industrial firms (unregulated firms) due to the substitution of regulation for 
private monitoring.

In line with prior literature on the significant relation between board and ownership structures and bank performance, we expect that bank performance will be positively affected by the quality of governance. We propose the hypothesis that bank performance is likely to be positively associated with the level of bank governance quality.

\section{$H_{1}$ : Bank performance is positively associated with the level of bank governance quality}

\section{Research Methodology}

The purpose of this study is to examine the relation between bank governance quality and performance. We create OLS regression models for this purpose and test for a relation by using cross sectional, time-series regression analyses design. In this section, we present the sample of the study, model specification and variables definition.

\subsection{Study Sample}

The sample consists of 48 banks operating in Egypt with data covering the period 2000-2009. The sample selection policy for the hypothesis $\left(\mathrm{H}_{1}\right)$ is described in Table 1 below. To be included in the sample, a bank must meet the following sample selection criteria (see Table 1):

1) Bank is subject to CBE supervision and the 2003 Banking Law jurisdiction.

2) The bank must not be a branch of a foreign bank.

3) Financial and governance data are available from Bankscope and Kompass Egypt (Note 3)(Note 4) databases, respectively, for at least three years during the period 2000-2009.

Table 1. Sample Selection Criteria

\begin{tabular}{lcc}
\hline Criterion & Number & Percent \\
\hline Total number of banks available from Kompass Egypt and & 62 & 100.00 \\
Bankscope during 2000-2009 & & \\
Less: Branches of foreign banks & 57 & $(8.10)$ \\
Subtotal & $(9)$ & 91.90 \\
Less: banks with less than 3 continuous years of data on & & $(14.50)$ \\
Kompass Egypt and Bankscope & $\mathbf{4 8}$ & $\mathbf{7 7 . 4 0}$ \\
Final number of banks in the sample
\end{tabular}

To enhance the power of the empirical analysis, we pool observations across years for the period 2000-2009. No bank may be represented more than once in the sample. This policy results in a maximum number of observations of 480 bank-years (48 banks in 10 years) comprising the final sample for hypothesis testing. However, because many data items are missing, number of observations per variable may be lower.

\subsection{Variable Definitions and Model Specification}

In this section, the test model and the variable definitions is introduced. Table 2 presents a list of variables and the data sources. Financial and governance data were obtained from Bankscope database, KOMPASS EGYPT, and bank financial statement.

\subsubsection{Corporate Governance Quality Index}

In determining an overall corporate governance score, the first challenge is that prior research does not agree on a single corporate governance measure (DeFond et al., 2004; and Gompers et al., 2003). However, we follow prior literature in measuring governance quality using a self-constructed index. Specifically, we proxy for the bank governance quality using a multidimensional index comprised of six governance indicators: Board structure consisting of board size (Linck et al., 2008), and board composition (Beasley, 1996), leadership structure proxied by CEO/Chairman duality (Brickley et al., 1997; Goyal and Park, 2002), and ownership structure proxied by percentage of institutional investor ownership (Cornett, 2007), percentage of foreign ownership (Chow and Boren, 1987), and percentage ownership of largest blockholder (Abbott et al., 2003) (Note 5).

Board size is measured as the number of directors on the board (Staikouras et al., 2007; Coles et al., 2008; and Belkhir, 2009). In financial firms, many studies documented that banking firms have larger boards that have positive effect on performance, for example, Subrahmanyam et al. (1997), and Andres and Vallelado (2008). The reasons behind the large boards of banks are the large firm size in terms of total assets (Staikouras et al., 2007; and Linck et al., 2008), the increase of mergers and acquisitions activity in banks which cause restructuring in boards, and complicated structure of banks (Adams and Mehran, 2005). Therefore, we predict banks with large boards have 


\section{higher performance.}

Board composition is measured as proportion of non-executives directors on the board (Vafeas, 1999). Literature on board independence can be classified into two groups of studies. One group encourages the presence of outsiders and argues that it has a positive effect on performance due to the effective monitoring of outsiders (Subrahmanyam et al., 1997; and Belkhir, 2009). The other group argues that insiders are more effective in enhancing firm performance due to their firm-specific knowledge and information (Coles et al., 2008), and suggest that independent directors decrease bank performance (Pathan and Faff, 2013). As banks are large, have a complicated structure and are frequently involved in mergers activities, we predict that more non-executive directors will enhance banks' performance.

$C E O /$ Chairman duality is measured by a dummy variable that takes the value of 0 if the CEO is also the Chairman, and 1 otherwise. We follow Brickley et al. (1997) in defining the duality of leadership as the case where the two positions of the CEO and Chairman are held by two different persons, while in non-duality leadership (the unitary leadership structure) the two positions of the $\mathrm{CEO}$ and Chairman are held by one person. This means that duality will refer to two separate leaders and non-duality will mean that the CEO and the Chairman is one person. Thus, Brickley et al. (1997) use the words duality and non-duality to describe the status of the positions in the organization.

Many studies reported a negative relationship between bank performance and the combination of the CEO and Chairman titles in one person, for example, Pi and Timme (1993), Booth et al. (2002). However, in contrast to those studies, Brickley et al. (1997) argue that combining the titles of the CEO and Chairman in one person is efficient and improves performance and separation will cause information cost for the incomplete transfer of critical information between the $\mathrm{CEO}$ and the chairman, and costs resulting from the extra compensation for the chairman. Following the first group of studies, we predict that the separation between the CEO and Chairman positions will have positive effect on bank performance.

Ownership concentration is the proportion of shares held by the largest blockholder (Claessens et al., 2002). Large shareholders will better monitor management especially in case of weak or limited shareholders protection rights, and they also play an important role in takeovers (Shleifer and Vishny, 1986). Moreover, ownership concentration reduces bank non-performing loans ratio, improves the capital adequacy ratio, reduces bank risk (Shehzad et al., 2010), and lower insolvency risk (Iannotta et al., 2007). Concentrated ownership is thus an important tool for monitoring complicated bank structures and achieving high bank performance. We predict that bank performance to be positively related to concentrated ownership.

Foreign ownership is the proportion of shares held by foreign investors (Iannotta et al., 2007). Due to international differences in accounting standards and cultural norms, foreign investors are expected to demand more information from firm management. The increased transparency in bank reporting is expected to motivate banks to improve performance. We therefore, predict that performance would increase in proportion to increase in foreign ownership.

Institutional ownership is measured by the proportion of shares held by non-foreign institutional investors, including the Egyptian government. Institutional investors' ownership of large block of shares in large firms enables them to pressure managers for better performance as good corporate governance is a function of large shareholding and effective legal protection.(La Porta et al., 1997). Therefore, we predict that bank performance is positively related to the level of institutional ownership.

If variables are not already in percentage or standardized terms, aggregating variables without standardization will cause the index to be dominated by implicit weights coming from the units and range used to measure variables (Salzman, 2003). To determine the optimal weights for each governance variable in the index, we use principal-components factor analysis to group the six variables into a single governance score $(G O V)$ and into the two major governance components: Board structure (BSTRUC) and Ownership structure (OSTRUC) (Note 6). The board structure component is comprised of board size, composition and CEO/Chairman duality. The ownership structure component is comprised of the percentage ownership by foreigners, institutional investors and largest blockholder.

\subsubsection{Performance variables and Balanced Scorecard measure}

The Balanced Scorecard (BSC) is a performance measurement system introduced by Kaplan and Norton (1992). It gained increasing popularity as an effective management tool because it shifts the focus of the performance measurement system from the short-term financial-based measures to the long term customer-centric measures. BSC measures performance through an integrated multi-level Financial, Customer, Internal Business Processes, and Learning and Growth indicators, customized for the use of individual firms. 
Many studies empirically test the relation between using the BSC and improved performance in the service sector (especially banks) and suggest that non-financial measures are as important as the financial measures to depict a balanced picture for current performance and future performance (for example, Brewer et al., 2004; and Wang, 2005). Therefore, due to the importance of the application of the BSC in the banking industry, we measure bank performance using a multidimensional BSC-based performance index. We use principal-components factor analysis to create a performance index comprising the four main BSC categories: financial, customer, internal business processes, and learning and growth (Note 7). Table 2 shows the performance-related variable definitions.

\section{Financial Perspective}

In general, the financial measures of profitability most widely used in prior research are the return on assets $(R O A)$ and the return on equity (ROE) or variations of these. $R O A$ reflects the ability of a bank's management to generate profits from assets, while ROE indicates the return to shareholders on their equity. In general, $R O A$ is a more popular measure in prior research because it measures the return generated by the bank to all resource providers (equity, debt and retained earnings) and not just to a single group like the ROE. Also, $R O A$ is more sensitive to a bank's financial leverage, measured as debt-to-assets. ROA is calculated as ROE times the ratio of equity to assets, which is often referred to as the financial leverage.

Banks with higher (lower) equity base will have lower (higher) financial leverage ratio, and therefore lower (higher) ROE. Since the banking industry by default is characterized by an extremely high financial leverage (due to its dependence on deposits as the primary source of financing), ROE would be biased upwards disregarding the different forms of risk to the other resource provider groups (especially depositors). Also, financial leverage is often determined by regulation and hence is not sensitive to variations in bank performance, like the $R O A$, which is recommended as the key ratio for the evaluation of bank profitability (IMF, 2002). Both ROA and ROE are measured as running year averages because assets and equity are balance sheet figures that are reported at fiscal period-end only, while income is an income statement figure that represent fiscal period-round operations. To match the numerator and denominator periods, we use average assets figures. We follow prior literature in measuring a bank's financial performance using average return on assets, $R O A$, measured as net income divided by average total assets. Further, we adjust $R O A$ for industry average to control against industry wide fluctuations.

\section{Customer perspective}

The second layer in the BSC is the customer-related set of performance indicators. The set of indicators employed by a firm is determined by the nature of industry, products/services offered, and firm strategy. Prior studies focusing on the banking sector use a variety of proxies for customer-related performance. Some of the measures used in these studies include bank's share in total deposits in the country and bank's share in total assets in the country. We follow Laeven and Levine (2009) in using a bank's deposit market share, DMKTSH, calculated as a bank's share in total deposits in the country, as a proxy for customer-related performance. We adjust DMKTSH for the industry average to control against industry wide fluctuations.

\section{Internal business Processes Perspective}

The third layer in the BSC is performance indicators related to internal business processes. When applied to the banking sector, the indicators measure how successful a bank is in improving the internal management of operations, such as time needed to conduct services and cost of performing services. The total cost of a bank (net of interest payments) can be separated into operating cost and other expenses (including taxes, depreciation etc.). From the above, only operating expenses can be viewed as the outcome of bank management (Athanasoglou et al., 2008). The ratio of these expenses to a benchmark (such as total operating revenues or total assets) is expected to be negatively related to profitability, since improved management of these expenses will increase efficiency and therefore raise profits. We follow Athanasoglou et al. (2008) in using operating efficiency, OPEFF, calculated as total operating expenses divided by total operating revenues, in measuring a bank's internal business processes. We adjust OPEFF for the industry average to control against industry-wide fluctuations.

\section{Learning and Growth Perspective}

The final layer in the BSC is bank learning and growth indicators. The learning and growth measures quantify the degree to which the banking organization has grown in capacity due to increased learning. Examples include moving upwards on the learning curve and developing new product/services. Prior literature focusing on the banking sector uses a variety of measures to proxy for learning growth. We follow Wang (2005) in using employee productivity, $P R O D$, calculated as the natural logarithm of the product of dividing total operating income by the number of employees, in measuring bank learning and growth. We adjust $P R O D$ for the industry average to control against 
industry wide fluctuations.

\section{Performance Composite Index}

To assess the overall bank performance, we combine the measures from each of the four performance layers: financial, customer, internal business processes and learning and growth, into a single composite factor. As described above, we measure these layers using bank ROA, deposit market share, operating efficiency and employee productivity, respectively. We use principle-components factor analysis to determine the optimal weights for each of the four indicators in the index. The measures passed the reliability analysis necessary before conducting factor analysis. The composite index, $P E R F$, represents the overall bank performance on the four scales. Similar to the procedure conducted on the individual components, we adjust PERF for the industry average to control against industry wide fluctuations.

\subsubsection{Performance Control Variables}

We follow prior literature in controlling for specific factors deemed significant in explaining variation in bank performance. Prior research contends that the following are important predictors of bank performance:

Managerial efficiency: We follow Naceur and Kandil (2009) in measuring management efficiency, MEFF, as earning assets to total assets. We expect MEFF to have a positive relation to performance.

Size: Size may be an important determinant of bank performance due to the increasing returns to scale in banking (Demirgüç-Kunt et al., 2004). We follow prior research in measuring bank size, SIZE, as the natural logarithm of total assets (Demirgüç-Kunt et al., 2004: and Naceur and Kandil 2009). We expect SIZE to have a positive relation to performance.

Capital adequacy: Some theories suggest that well-capitalized banks face lower expected bankruptcy costs and hence lower funding costs. According to this view, higher bank equity ratios imply larger net interest margins when loan rates do not vary much with bank equity and hence better performance. Many studies argue that the capital adequacy variable (measured as capital divided by total assets) has a positive effect on performance (Berger et al., 1995 and Goddard et al., 2004). We use the variable CAPADQ to control for capital adequacy, and we expect it to have a positive relation to performance.

Liquidity: To control for differences in bank assets, we use LIQ, equals the liquid assets of the bank divided by total assets. Banks with high levels of liquid assets in cash and government securities may receive lower interest income than banks with less liquid assets (Naceur and Kandil, 2009). If the market for deposits is reasonably competitive, then greater liquidity will tend to be negatively associated with interest margins. LIQ is expected to be negatively associated with performance.

Non-interest revenue: We follow prior research in controlling for non-interest bank revenue as banks have different product mixes. These differences may influence the pricing of loan products. Studies argue that well-developed fee income sources will produce income due to cross-subsidization of bank activities (Naceur and Kandil, 2009). Thus, we control for fee income in assessing the impact of bank regulations on bank performance. We proxy for non-interest revenue using the variable FEE, defined as non-interest-operating income divided by total assets. We expect that FEE would be positively related to performance.

Credit risk: Some hold that banks operating in more risky environment will tend toward an equilibrium characterized by a high net interest margin to compensate for this risk (Naceur and Kandil, 2009). Banks are increasing spreads between lending and deposit interest rate to protect against the increase in credit risk (Barajas et al., 1999). We use the LLP, percentage of loan-loss provisions to total loans as a proxy for credit risk, and expect a negative relation with performance.

Real GDP growth: In periods of real GDP growth, economic activity is above average and banks would benefit from the upward activity level, especially that the level of economic activity at banks is normally positively correlated to Egyptian economic activity. We control for overall economic activity using the variable GDPGRO, which is defined as the annual GDP growth rate in Egypt in real terms, as declared by the Ministry of Finance. We expect the relation between GDPGRO and performance to be positive.

Inflation expectations: The relation between expected inflation and profitability is not clear in the literature. We expect that rising inflationary expectations would have two negative effects that would result in bank profitability and performance suffering. First, inflation would reduce discretionary income for final consumers and would thus create a difficult situation for Egyptian firms, who may react by reducing their level of investment and by reducing their borrowing plans. Second, due to the slower business activity for firms, businesses may be unwilling to engage 
in long-term borrowing if they expect that debt burden may increase over time, especially for variable-rate loans. However, Athanasoglou et al. (2008) argue that bank managers forecast future inflation and adjust the interest rates appropriately in order to achieve higher profits, and on the other hand, bank customers fail to anticipate inflation correctly. Thus, interest rate on bank deposits will decrease at a faster rate than the interest rate on loans; therefore, there will be a positive relationship between bank profitability and inflation.

Table 2. Variables Definition

\begin{tabular}{|c|c|c|c|c|c|}
\hline \multicolumn{6}{|c|}{ Dependent Variables } \\
\hline \multirow[t]{5}{*}{ Construct } & Dimensions/Variables & Code & \multirow{2}{*}{\multicolumn{2}{|c|}{ Number of directors on the board }} & Source \\
\hline & Board size & BSIZE & & & KOMPASS EGYPT \\
\hline & Board structure & COMP & \multicolumn{2}{|c|}{ Proportion of non-executives directors on the board, $\%$} & KOMPASS EGYPT \\
\hline & Leadership structure & DUAL & \multicolumn{2}{|c|}{$\begin{array}{l}\text { Dummy variable ( } 0 \text { if the CEO is also the board chair, } 1 \text { otherwise). Duality refers to two positions held by two } \\
\text { different persons (CEO isn't Chairman) and non-duality refer to two positions held by one person (CEO is Chairman }\end{array}$} & KOMPASS EGYPT \\
\hline & Ownership concentration & $\mathrm{Cl}$ & \multicolumn{2}{|c|}{ Proportion of shares held by the largest blockholder, $\%$} & KOMPASS EGYPT \\
\hline \multirow{6}{*}{$\begin{array}{l}\text { Governance } \\
\text { quality }\end{array}$} & Foreign ownership & FOR & \multicolumn{2}{|c|}{ Proportion of shares held by foreign investors, $\%$} & KOMPASS EGYPT \\
\hline & Institutional ownership & INST & \multirow{2}{*}{\multicolumn{2}{|c|}{$\begin{array}{l}\text { Proportion of shares held by non-foreign institutional investors, including the Egyptian government, \% } \\
\text { Bank i's corporate governance quality score in year } t \text {, measured as a multidimensional composite index generated by } \\
\text { factor analysis of bank i's score in year t on each of the following indicators: board size, board composition, } \\
\text { CEO/Chairman duality, institutional ownership percentage, foreign ownership percentage, and largest blockholder } \\
\text { ownership percentage }\end{array}$}} & KOMPASS EGYPT \\
\hline & Governance index & GOV & & & Factor Analysis \\
\hline & Financial & ROA & \multicolumn{2}{|c|}{ Return on assets: Net income divided by average assets, $\%$} & $\begin{array}{l}\text { Bankscope } \\
\text { Bank Fin. Statements }\end{array}$ \\
\hline & Customer & DMKTSH & \multicolumn{2}{|c|}{ Deposit market share: Bank deposits divided total deposits of all banks, $\%$} & $\begin{array}{l}\text { Bankscope } \\
\text { Bank Fin. Statements }\end{array}$ \\
\hline & $\begin{array}{l}\text { Internal business } \\
\text { processes }\end{array}$ & OPEFF & \multicolumn{2}{|c|}{ Operating efficiency: Total operating expenses divided by total operating revenues, $\%$} & $\begin{array}{l}\text { Bankscope } \\
\text { Bank Fin. Statements }\end{array}$ \\
\hline \multirow{3}{*}{ Performance } & Learning and growth & PROD & \multicolumn{2}{|c|}{ Employee productivity: Log of (operating income/ no. of employees) } & $\begin{array}{l}\text { Bankscope } \\
\text { Bank Fin. Statements }\end{array}$ \\
\hline & $\begin{array}{l}\text { Performance composite } \\
\text { Index }\end{array}$ & PERF & \multicolumn{2}{|c|}{$\begin{array}{l}\text { Bank performance score, measured as a multidimensional composite index generated by factor analysis of bank i's } \\
\text { score in year } t \text { on each of the following indicators: Return on assets, Deposit market share, Operating efficiency and } \\
\text { Employee productivity }\end{array}$} & Factor Analysis \\
\hline & & & \multicolumn{2}{|c|}{ Control Variables } & \\
\hline Construct & Dimensions/Variables & Code & predicted sign & Measurement & Source \\
\hline \multirow{4}{*}{ Risk } & Liquidity & $L I Q$ & - & Liquid assets of the bank divided by total assets. & $\begin{array}{l}\text { Bankscope } \\
\text { Bank Fin. Statements }\end{array}$ \\
\hline & Capital adequacy & $C A P A D Q$ & + & Book value of equity to total assets. & $\begin{array}{l}\text { Bankscope } \\
\text { Bank Fin. Statements }\end{array}$ \\
\hline & Credit risk & $L L P$ & - & Loan loss provisions: Total loan losses divided by total loans, $\%$ & $\begin{array}{l}\text { Bankscope } \\
\text { Bank Fin. Statements }\end{array}$ \\
\hline & Real GDP Growth & GDPGRO & + & Official annual real GDP growth figures, $\%$ & Ministry of Finance \\
\hline \multirow{3}{*}{$\begin{array}{l}\text { Macro- } \\
\text { economic and } \\
\text { other }\end{array}$} & Inflation Rate & CPI & + & Official annual Consumer Price Index $(C P I), \%$ & Ministry of Finance \\
\hline & Time Effect & YearCode & + & Categorical variable representing code of year $t$ & Author-constructed \\
\hline & Global Financial Crisis & CRISIS & - & Dummy assuming the value of 1 if the data year is 2008 and 0 otherwise & Author-constructed \\
\hline \multirow{3}{*}{$\begin{array}{l}\text { Bank } \\
\text { characteristics }\end{array}$} & Bank size & SIZE & + & Natural logarithm of total assets & $\begin{array}{l}\text { Bankscope } \\
\text { Bank Fin. Statements }\end{array}$ \\
\hline & Management efficiency & MEFF & + & Income-earning assets divided by total assets & Bankscope, Bk stat \\
\hline & Fee income & FEE & + & Non-interest operating income divided by total assets & Bankscope, Bk stat \\
\hline
\end{tabular}

Following Athanasoglou et al. (2008), we use current inflation as a proxy for expected inflation. We measure current inflation as CPI, the annual Consumer Price Index announced by the Egyptian Ministry of Finance. We expect a positive relation between $C P I$ and performance.

Global banking crisis: The year 2008 was characterized by the exacerbation of the global banking crisis, which is expected to have a negative impact on the Egyptian banking sector. Even though Egyptian government officials claim that the crisis did not affect the Egyptian banking sector significantly, the event has to be controlled for due to its potential impact on the research model. We use CRISIS, a dummy variable that assumes the value of 1 if the data year is 2008 and 0 otherwise. We expect a negative relation between CRISIS and performance.

Time effect: In addition to the above control variables, we also include in the model a control variable that represents the number of years over which the study analysis extends. As explained earlier, we include in the sample five years of data before and after each merger (ten years in total), and, although the number of years in some cases may go down to only two years before and after the merger, the number of years should be included in the model because changes in performance may simply be due to organizational learning, rather than law promulgation. Therefore, we use the categorical variable YearCode, representing the year of the data item relative to the merger year (that is, Year $\mathrm{t}-5$ to Year $\mathrm{t}+4$ ). We expect a positive relation between YearCode and performance.

\subsection{Estimation of Bank Governance Quality and Performance equation}

To test the study hypothesis, we create a multivariate cross-sectional model that tests the impact of bank governance quality on bank performance, measured using the BSC approach. The main independent variable bank governance quality, $G O V$, also has been defined above, as a multidimensional composite index generated by factor analysis of 
bank score on each of the following indicators: board size, board composition, CEO/Chairman duality, institutional ownership percentage, foreign ownership percentage, and largest blockholder ownership percentage.

We estimate an OLS regression model using PERF as the dependent variable in the Model 1, and GOV is the primary explanatory variable. The control variables are added to the model in various combinations to determine their importance in determining performance. The primary analysis involves an examination of the significance of the coefficient of the primary variable $G O V$. Finding a significant coefficient is consistent with the theory indicating that governance quality is an important influence on bank performance in Egypt.

Model 1: Bank performance $=f$ (Governance quality, Control variables)

$P E R F_{t}=\beta_{0}+\beta_{1} G O V_{i t}+\beta_{2} L I Q_{i t}+\beta_{3} C A P A D Q_{i t}+\beta_{4} L L P_{i t}+\beta_{5} M E F F_{i t}+\beta_{6} F E E+\beta_{7} G D P G R O_{i t}+\beta_{8} S I Z E_{i t}+\beta_{9}$

$C P I_{i t}+\beta_{10}$ CRISIS $+\beta_{11}$ YearCode $_{i t}+\mathrm{e}_{\mathrm{j}}$ (Model 1)

Variable definitions are shown in Table 2; $e_{i t}=$ Error term

Coefficient $\beta_{1}$ represents the coefficient estimate for the corporate governance quality composite index score testing the hypothesized relationship, while $\beta_{2}$ through $\beta_{10}$ represent the coefficient estimates for the control variables suggested by prior literature as determinants of performance. $\beta_{12}$ represents time effect to control for events peculiar to each year in the analysis.

\section{Empirical Results}

In this section, we describe the empirical results of testing Model 1, where we regress performance on bank governance quality and a set of relevant control variables. Table 3 presents the statistics for model 1 . It is important to note that financial indicators are industry-adjusted, that is, the industry average for each variable was deducted from the data value of each bank in order to control for industry-wide fluctuations.

\subsection{Descriptive statistics}

Table 3 shows the mean GOV and governance components (BSIZE, COMP, FOR, INST, DUAL, and C1) scores in each $G O V$ quartile. In the best-governed banks (fourth GOV quartile), the average bank is characterized by the following mean values: board size of 6.86 members, non-executives representing $75.85 \%$ of the board, and separation of $\mathrm{CEO} /$ Chairman positions.

Table 3. Descriptive Statistics

\begin{tabular}{|c|c|c|c|c|c|c|c|c|c|}
\hline Variable & $\begin{array}{c}\text { GOV } \\
\text { Quartiles }\end{array}$ & $\mathbf{N}$ & Min & Q1 & Mean & Median & Q3 & Max & Std Dev \\
\hline \multicolumn{10}{|c|}{ Governance Quality } \\
\hline \multirow{4}{*}{ GOV } & 1 & 86 & -2.280 & -1.316 & -1.184 & -1.127 & -0.914 & -0.494 & 0.366 \\
\hline & 2 & 78 & -0.876 & -0.630 & -0.358 & -0.361 & -0.191 & 0.292 & 0.322 \\
\hline & 3 & 80 & -0.255 & 0.007 & 0.323 & 0.292 & 0.577 & 1.475 & 0.416 \\
\hline & 4 & 83 & 0.360 & 0.702 & 1.253 & 1.460 & 1.630 & 2.257 & 0.538 \\
\hline \multirow{4}{*}{ BSIZE } & 1 & 86 & 5.000 & 9.000 & 11.221 & 11.000 & 13.000 & 24.000 & 3.145 \\
\hline & 2 & 78 & 3.000 & 8.000 & 10.859 & 10.000 & 14.000 & 24.000 & 4.698 \\
\hline & 3 & 80 & 2.000 & 7.000 & 8.038 & 8.000 & 9.500 & 13.000 & 2.230 \\
\hline & 4 & 83 & 3.000 & 6.000 & 6.855 & 7.000 & 8.000 & 9.000 & 1.690 \\
\hline \multirow{4}{*}{ СОМР } & 1 & 86 & 54.545 & 84.615 & 86.731 & 88.889 & 90.909 & 94.444 & 7.462 \\
\hline & 2 & 78 & 50.000 & 83.333 & 85.815 & 88.889 & 92.857 & 100.000 & 10.400 \\
\hline & 3 & 80 & 33.333 & 75.000 & 78.703 & 85.714 & 88.889 & 92.308 & 14.327 \\
\hline & 4 & 83 & 33.333 & 66.667 & 75.847 & 83.333 & 87.500 & 100.000 & 17.576 \\
\hline \multirow{4}{*}{ DUAL } & 1 & 86 & 0.000 & 0.000 & 0.186 & 0.000 & 0.000 & 1.000 & 0.391 \\
\hline & 2 & 78 & 0.000 & 0.000 & 0.410 & 0.000 & 1.000 & 1.000 & 0.495 \\
\hline & 3 & 80 & 0.000 & 0.000 & 0.388 & 0.000 & 1.000 & 1.000 & 0.490 \\
\hline & 4 & 83 & 0.000 & 1.000 & 0.771 & 1.000 & 1.000 & 1.000 & 0.423 \\
\hline \multirow{4}{*}{ FOR } & 1 & 86 & 0.000 & 0.000 & 10.259 & 0.000 & 18.700 & 55.000 & 14.716 \\
\hline & 2 & 78 & 0.000 & 0.000 & 23.289 & 35.704 & 40.000 & 70.250 & 21.657 \\
\hline & 3 & 80 & 0.000 & 0.000 & 37.191 & 40.170 & 63.015 & 95.350 & 32.892 \\
\hline & 4 & 83 & 0.000 & 49.000 & 68.011 & 78.400 & 95.360 & 100.000 & 33.998 \\
\hline \multirow{3}{*}{ INST } & 1 & 86 & 0.000 & 31.100 & 57.075 & 71.900 & 79.840 & 100.000 & 29.254 \\
\hline & 2 & 78 & 23.060 & 71.760 & 82.353 & 84.655 & 100.000 & 100.000 & 20.127 \\
\hline & 3 & 80 & 65.910 & 77.460 & 89.820 & 97.275 & 100.000 & 100.000 & 12.053 \\
\hline Published by Sci & Press & & & 68 & & $I S S I$ & $1927-5986$ & E-ISSN I & $27-5994$ \\
\hline
\end{tabular}




\begin{tabular}{|c|c|c|c|c|c|c|c|c|c|}
\hline \multirow{5}{*}{ C1 } & 4 & 83 & 70.000 & 98.200 & 97.637 & 99.614 & 100.000 & 100.000 & 6.012 \\
\hline & 1 & 86 & 3.650 & 17.840 & 28.398 & 22.490 & 32.100 & 100.000 & 19.891 \\
\hline & 2 & 78 & 13.820 & 25.200 & 48.010 & 40.000 & 59.440 & 100.000 & 30.072 \\
\hline & 3 & 80 & 16.660 & 39.730 & 62.171 & 51.000 & 95.350 & 100.000 & 29.863 \\
\hline & 4 & 83 & 33.260 & 60.000 & 81.637 & 94.527 & 99.300 & 100.000 & 21.611 \\
\hline \multicolumn{10}{|c|}{ Performance } \\
\hline \multirow{4}{*}{ PERF } & 1 & 86 & -2.467 & -0.431 & 0.024 & -0.070 & 0.340 & 2.478 & 0.746 \\
\hline & 2 & 78 & -4.269 & -0.444 & -0.190 & -0.240 & 0.261 & 1.418 & 0.845 \\
\hline & 3 & 80 & -2.684 & -0.655 & 0.039 & -0.174 & 0.703 & 4.217 & 0.945 \\
\hline & 4 & 83 & -1.537 & -0.255 & 0.329 & 0.232 & 1.001 & 2.325 & 0.875 \\
\hline \multirow{4}{*}{ ROA } & 1 & 86 & -5.191 & -0.601 & 0.097 & -0.140 & 0.768 & 3.798 & 1.541 \\
\hline & 2 & 78 & -9.157 & -0.654 & -0.150 & -0.312 & 0.705 & 2.590 & 1.481 \\
\hline & 3 & 80 & -6.593 & -0.565 & -0.068 & -0.308 & 0.760 & 1.686 & 1.113 \\
\hline & 4 & 83 & -4.218 & -0.548 & 0.293 & 0.206 & 1.115 & 2.956 & 1.222 \\
\hline \multirow{4}{*}{ DMKTSH } & 1 & 86 & -2.814 & -1.573 & -1.325 & -1.416 & -1.186 & 0.235 & 0.426 \\
\hline & 2 & 78 & -2.375 & -1.584 & -0.577 & -1.423 & -0.891 & 6.693 & 2.118 \\
\hline & 3 & 80 & -1.715 & -1.531 & -0.371 & -1.189 & -0.249 & 5.864 & 1.898 \\
\hline & 4 & 83 & -2.938 & -1.591 & -0.749 & -1.399 & -1.041 & 6.265 & 1.927 \\
\hline \multirow{4}{*}{ OPEFF } & 1 & 86 & -81.974 & -20.460 & 30.018 & 2.306 & 22.574 & 339.811 & 105.510 \\
\hline & 2 & 78 & -89.468 & -14.992 & 43.323 & 7.875 & 24.919 & 690.754 & 130.724 \\
\hline & 3 & 80 & -75.682 & -16.358 & 23.052 & -1.296 & 16.662 & 340.632 & 91.552 \\
\hline & 4 & 83 & -88.642 & -27.185 & 21.994 & 0.822 & 17.226 & 376.104 & 98.812 \\
\hline \multirow{4}{*}{ PROD } & 1 & 86 & -1.508 & -0.323 & -0.060 & 0.014 & 0.265 & 1.392 & 0.579 \\
\hline & 2 & 78 & -2.209 & -0.429 & -0.187 & -0.152 & 0.281 & 1.121 & 0.714 \\
\hline & 3 & 80 & -0.993 & -0.474 & 0.138 & -0.011 & 0.693 & 2.300 & 0.722 \\
\hline & 4 & 83 & -0.889 & 0.064 & 0.446 & 0.455 & 0.911 & 1.303 & 0.567 \\
\hline \multicolumn{10}{|c|}{ Risk Indicators } \\
\hline \multirow{5}{*}{ LLP } & 1 & 86 & -4.531 & -0.934 & 0.553 & -0.369 & 1.806 & 7.554 & 2.840 \\
\hline & 2 & 78 & -5.325 & -1.295 & 0.016 & -0.292 & 1.127 & 10.240 & 2.342 \\
\hline & 3 & 80 & -4.327 & -1.511 & -0.386 & -0.438 & 0.264 & 16.513 & 2.653 \\
\hline & 4 & 83 & -5.524 & -1.460 & -0.158 & -0.577 & 0.463 & 10.048 & 2.772 \\
\hline & 1 & 86 & -22.693 & -3.551 & -0.871 & -1.204 & 1.430 & 13.129 & 6.246 \\
\hline \multirow{3}{*}{ CAPADQ } & 2 & 78 & -7.609 & -4.539 & -1.222 & -1.676 & 1.535 & 15.186 & 4.439 \\
\hline & 3 & 80 & -6.909 & -4.367 & -1.468 & -2.414 & -0.707 & 15.297 & 4.724 \\
\hline & 4 & 83 & -6.191 & -3.045 & 0.034 & -1.192 & 1.688 & 13.564 & 4.483 \\
\hline \multirow{4}{*}{ LIQ } & 1 & 86 & -27.971 & -6.057 & 5.684 & 1.417 & 16.619 & 69.966 & 20.853 \\
\hline & 2 & 78 & -77.213 & -21.172 & -9.763 & -10.676 & -2.686 & 57.926 & 23.680 \\
\hline & 3 & 80 & -61.473 & -19.322 & -2.144 & -10.154 & 1.259 & 151.777 & 38.368 \\
\hline & 4 & 83 & -38.213 & -21.783 & -14.723 & -15.508 & -6.821 & 34.352 & 12.606 \\
\hline \multicolumn{10}{|c|}{ Bank Characteristics } \\
\hline \multirow{4}{*}{ SIZE } & 1 & 86 & -2.353 & -1.192 & -0.669 & -0.647 & -0.221 & 0.838 & 0.690 \\
\hline & 2 & 78 & -1.956 & -1.258 & -0.447 & -0.913 & 0.203 & 2.231 & 1.097 \\
\hline & 3 & 80 & -1.640 & -1.126 & -0.019 & -0.100 & 0.656 & 2.504 & 1.155 \\
\hline & 4 & 83 & -3.261 & -1.486 & -0.655 & -0.739 & -0.115 & 2.413 & 1.304 \\
\hline \multirow{4}{*}{ MEFF } & 1 & 86 & -10.015 & 1.798 & 3.499 & 4.505 & 5.447 & 9.632 & 3.159 \\
\hline & 2 & 78 & -26.251 & 0.029 & 1.850 & 2.659 & 5.293 & 8.532 & 5.109 \\
\hline & 3 & 80 & -24.199 & -1.919 & 0.117 & 2.653 & 4.192 & 8.528 & 7.117 \\
\hline & 4 & 83 & -4.019 & 0.741 & 2.990 & 3.028 & 5.446 & 10.006 & 3.074 \\
\hline \multirow{4}{*}{ FEE } & 1 & 86 & -1.523 & -0.668 & -0.119 & -0.225 & 0.274 & 3.021 & 0.764 \\
\hline & 2 & 78 & -1.845 & -0.778 & -0.117 & -0.131 & 0.334 & 2.171 & 0.835 \\
\hline & 3 & 80 & -1.842 & -0.596 & -0.211 & -0.247 & 0.148 & 3.292 & 0.806 \\
\hline & 4 & 83 & -2.233 & -0.752 & -0.145 & -0.194 & 0.268 & 3.869 & 1.044 \\
\hline
\end{tabular}

Notes: This table shows the statistics of the variables, broken down by governance quality score (GOV) quartiles. GOV is divided into four quartiles ( 1 represents the lowest quality and 4 represents the highest quality). 
On the ownership side, the best-governed banks have foreign ownership of $68.01 \%$, institutional ownership of $97.64 \%$, and largest block-holder ownership of $81.64 \%$. That is, the best-governed banks are characterized by relatively smaller boards, lower non-executive director proportion, separation of $\mathrm{CEO} / \mathrm{Chairman}$ positions, higher ownership percentage by foreigners and institutional investors, and higher ownership concentration.

In this study, all non-governance and non-macroeconomic measures are expressed in industry-averages. Thus, the interpretation of the figures should focus on the relative rankings of the variables rather than on the individual values (which in themselves would have little meaning). In terms of performance, well-governed banks have on average a higher performance index $(P E R F)$ score driven by higher financial performance $(R O A)$, deposit market share, operating efficiency, and productivity. Regarding control variables, capital adequacy and loan growth are higher compared to poorly governed banks. As for bank characteristics, well-governed banks have smaller size, lower managerial efficiency, and lower non-interest revenue sources.

\subsection{Correlation and regression analysis}

The correlations between performance, governance, and other control variables are represented below in Table 4 . Table 4 shows the Pearson correlation coefficients for the model variables. Bank performance is the dependent variable, and bank governance is the independent variable. PERF is significantly positively correlated with $G O V$, lending initial support to the study hypothesis. $P E R F$ is also significantly positively correlated with CAPADQ, FEE, and $M E F F$, but $P E R F$ is significantly negatively correlated with $L L P$ and $L I Q$.

Table 4. Pearson Correlation Coefficients for Model Variables $(\mathrm{n}=172)$

\begin{tabular}{|c|c|c|c|c|c|c|c|c|c|c|c|c|}
\hline & PERF & GOV & CRISIS & YearCode & LLP & CAPADQ & SIZE & LIQ & MEFF & FEE & CPI & GDPGRO \\
\hline \multirow{2}{*}{ PERF } & 1.00 & 0.19 & 0.01 & 0.05 & -0.47 & 0.40 & -0.09 & -0.11 & 0.24 & 0.14 & 0.03 & 0.05 \\
\hline & . & 0.01 & 0.42 & 0.25 & 0.00 & 0.00 & 0.11 & 0.07 & 0.00 & 0.04 & 0.34 & 0.25 \\
\hline \multirow{2}{*}{ GOV } & 0.19 & 1.00 & 0.15 & 0.21 & -0.19 & -0.07 & 0.09 & -0.33 & -0.02 & -0.23 & 0.14 & 0.23 \\
\hline & 0.01 & . & 0.02 & 0.00 & 0.01 & 0.17 & 0.11 & 0.00 & 0.40 & 0.00 & 0.03 & 0.00 \\
\hline \multirow{2}{*}{ CRISIS } & 0.01 & 0.15 & 1.00 & 0.70 & -0.12 & -0.03 & -0.01 & -0.01 & 0.18 & -0.33 & 0.54 & 0.77 \\
\hline & 0.42 & 0.02 & $\cdot$ & 0.00 & 0.05 & 0.35 & 0.46 & 0.44 & 0.01 & 0.00 & 0.00 & 0.00 \\
\hline \multirow{2}{*}{ Year_Code } & 0.05 & 0.21 & 0.70 & 1.00 & -0.16 & -0.04 & -0.02 & -0.06 & 0.11 & -0.32 & 0.79 & 0.88 \\
\hline & 0.25 & 0.00 & 0.00 & . & 0.01 & 0.30 & 0.40 & 0.21 & 0.07 & 0.00 & 0.00 & 0.00 \\
\hline \multirow{2}{*}{ LLP } & -0.47 & -0.19 & -0.12 & -0.16 & 1.00 & -0.07 & -0.17 & -0.06 & -0.10 & 0.31 & -0.18 & -0.14 \\
\hline & 0.00 & 0.00 & 0.05 & 0.01 & . & 0.19 & 0.01 & 0.23 & 0.11 & 0.00 & 0.01 & 0.04 \\
\hline \multirow{2}{*}{ CAPADQ } & 0.40 & -0.07 & -0.03 & -0.04 & -0.07 & 1.00 & -0.40 & 0.10 & 0.20 & 0.28 & 0.05 & -0.10 \\
\hline & 0.00 & 0.17 & 0.35 & 0.30 & 0.19 & . & 0.00 & 0.09 & 0.00 & 0.00 & 0.27 & 0.09 \\
\hline \multirow{2}{*}{ SIZE } & -0.09 & 0.10 & -0.01 & -0.02 & -0.17 & -0.40 & 1.00 & 0.10 & -0.26 & -0.24 & -0.00 & -0.03 \\
\hline & 0.11 & 0.11 & 0.46 & 0.40 & 0.01 & 0.00 & . & 0.09 & 0.00 & 0.00 & 0.50 & 0.34 \\
\hline \multirow{2}{*}{ LIQ } & -0.11 & -0.33 & -0.01 & -0.06 & -0.06 & 0.10 & 0.10 & 1.00 & 0.09 & 0.12 & 0.00 & -0.13 \\
\hline & 0.07 & 0.00 & 0.44 & 0.21 & 0.23 & 0.09 & 0.09 & · & 0.12 & 0.06 & 0.50 & 0.04 \\
\hline \multirow{2}{*}{ MEFF } & 0.24 & -0.02 & 0.18 & 0.11 & -0.09 & 0.20 & -0.26 & 0.09 & 1.00 & -0.06 & 0.10 & 0.08 \\
\hline & 0.00 & 0.40 & 0.01 & 0.07 & 0.11 & 0.00 & 0.00 & 0.12 & . & 0.22 & 0.10 & 0.15 \\
\hline \multirow{2}{*}{ FEE } & 0.14 & -0.23 & -0.33 & -0.32 & 0.31 & 0.28 & -0.24 & 0.12 & -0.06 & 1.00 & -0.30 & -0.35 \\
\hline & 0.04 & 0.00 & 0.00 & 0.00 & 0.00 & 0.00 & 0.00 & 0.06 & 0.22 & . & 0.00 & 0.00 \\
\hline \multirow{2}{*}{ CPI } & 0.03 & 0.14 & 0.54 & 0.79 & -0.18 & 0.05 & -0.00 & 0.00 & 0.10 & -0.30 & 1.00 & 0.56 \\
\hline & 0.34 & 0.03 & 0.00 & 0.00 & 0.01 & 0.27 & 0.50 & 0.50 & 0.10 & 0.00 & . & 0.00 \\
\hline \multirow{2}{*}{ GDPGRO } & 0.05 & 0.23 & 0.77 & 0.88 & -0.14 & -0.10 & -0.03 & -0.13 & 0.08 & -0.35 & 0.56 & 1.00 \\
\hline & 0.25 & 0.00 & 0.00 & 0.00 & 0.04 & 0.09 & 0.34 & 0.04 & 0.15 & 0.00 & 0.00 & . \\
\hline
\end{tabular}

Notes: This table presents Pearson correlations (above) and the p-value (below) in each cell. See Table 2 for variable definitions. $\mathrm{P}$-values below 0.10 are marginally significant, below 0.05 are significant, and below 0.01 are highly significant.

Table 5 represents the results of the regression analysis of Model 1. Bank performance is the dependent variable, while governance is the independent variable, in addition to control variables.

In further analysis, we decompose the sample into two categories based on governance quality score: high and low governance. Banks with a $G O V$ score that is equal to or greater than the median score are placed into a high group and those banks with a $G O V$ score that is lower than the median score are placed into a low group. We repeat the empirical testing of regression Model 1 for each group separately. Models tested on both groups are highly significant at the .01 level and have an $\mathrm{R}^{2}$ of 0.807 . The coefficient on the $G O V$ variable for the low group is positive and highly significant at the .01 level, while the coefficient on the $G O V$ variable for the high group is negative but 
insignificant. Results thus suggest that governance quality is a determinant of performance, particularly for banks in the low governance category. For the sake of brevity and simplifying the results presentations, we do not tabulate the results of the low/high analysis.

Table 5. Results of Model 1 Regression Analysis

\begin{tabular}{|c|c|c|c|c|c|c|c|c|}
\hline & & & \multicolumn{6}{|c|}{ Ex-Post Analysis } \\
\hline & \multicolumn{2}{|c|}{ Model 1} & \multicolumn{2}{|c|}{ Model 1 (a) } & \multirow{2}{*}{$\begin{array}{c}\text { Model } 1 \text { (b) } \\
\text { ROA } \\
\text { (6 Gov. Comp) } \\
\end{array}$} & \multirow{2}{*}{$\begin{array}{c}\text { Model } 1 \text { (c) } \\
\text { DMKTSH } \\
\text { (6 Gov. Comp) } \\
\end{array}$} & \multirow{2}{*}{$\begin{array}{c}\text { Model } 1 \text { (d) } \\
\text { OPEFF } \\
\text { (6 Gov. Comp) }\end{array}$} & \multirow{2}{*}{$\begin{array}{c}\text { Model } 1 \text { (e) } \\
\text { PROD } \\
\text { (6 Gov. Comp) } \\
\end{array}$} \\
\hline Dependent Variable & \multicolumn{2}{|r|}{ PERF } & \multicolumn{2}{|c|}{$\begin{array}{c}\text { PERF } \\
\text { (6 Gov. Comp) } \\
\end{array}$} & & & & \\
\hline & $\begin{array}{l}\text { Pred. } \\
\text { Sign }\end{array}$ & $\begin{array}{c}\text { Standardized } \\
\text { Coefficients }\end{array}$ & $\begin{array}{l}\text { Pred. } \\
\text { Sign }\end{array}$ & $\begin{array}{c}\text { Standardized } \\
\text { Coefficients }\end{array}$ & $\begin{array}{c}\text { Standardized } \\
\text { Coefficients }\end{array}$ & $\begin{array}{c}\text { Standardized } \\
\text { Coefficients }\end{array}$ & $\begin{array}{l}\text { Standardized } \\
\text { Coefficients }\end{array}$ & $\begin{array}{c}\text { Standardized } \\
\text { Coefficients }\end{array}$ \\
\hline GOV & + & $.103^{*}$ & 100 & 10000 & 10000 & $\$ 2000$ & 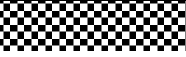 & 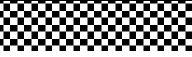 \\
\hline BSIZE & 383 & 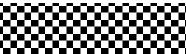 & + & -.045 & .060 & $-.100 * *$ & -.079 & $-.235^{* * *}$ \\
\hline COMP & 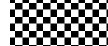 & n, & + & $-.112 *$ & $-.102 *$ & .014 & .047 & $-.125 * *$ \\
\hline$D U A L$ & 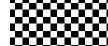 & 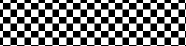 & + & .112 & .083 & .043 & -.051 & .072 \\
\hline$C 1$ & 383 & $\infty \infty^{\prime}$, & + & $-.321 * * *$ & -.061 & $.185^{* * *}$ & .009 & $-.527 * * *$ \\
\hline FOR & 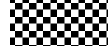 & 2* & + & $.304 * * *$ & .079 & $-.303 * * *$ & .004 & $.469 * * *$ \\
\hline INST & 383 & 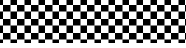 & + & .036 & -.071 & .049 & .010 & $.114^{*}$ \\
\hline$L L P$ & - & $-.495 * * *$ & - & $-.461 * * *$ & $-.634 * * *$ & $.118 * * *$ & $.496^{* * *}$ & -.038 \\
\hline$C A P A D Q$ & + & $.320 * * *$ & + & $.311 * * *$ & $.388 * * *$ & .010 & .000 & $.264 * * *$ \\
\hline$L I Q$ & - & $-.175^{* * *}$ & - & -.069 & $-.155^{* * *}$ & $-.165 * * *$ & $.114^{*}$ & $-.133 * *$ \\
\hline$F E E$ & + & $.282 * * *$ & + & $.295 * * *$ & $.276 * * *$ & -.035 & $-.385^{* * *}$ & $.136^{* *}$ \\
\hline$M E F F$ & + & $.192 * * *$ & + & .050 & .041 & .041 & -.033 & $.103 *$ \\
\hline$S I Z E$ & + & .080 & + & $.270 * * *$ & $.282 * * *$ & $.708 * * *$ & $-.118^{*}$ & $.497 * * *$ \\
\hline GDPGRO & + & .201 & + & .170 & .080 & -.027 & $.326^{* *}$ & .042 \\
\hline CPI & + & -.034 & + & -.070 & -.012 & .029 & .118 & -.116 \\
\hline CRISIS & - & -.077 & - & -.059 & .063 & .001 & $.518^{* * *}$ & -.125 \\
\hline YearCode & + & -.076 & + & -.006 & -.074 & .068 & $-.444 * * *$ & .148 \\
\hline \multicolumn{9}{|c|}{ Model Specification } \\
\hline F-Statistic & & $14.10 * * *$ & & $15.39 * * *$ & $18.48^{* * *}$ & $43.28 * * *$ & $17.42 * * *$ & $15.41 * * *$ \\
\hline $\mathbf{R}^{2}$ & & 0.48 & & 0.60 & 0.64 & 0.80 & 0.62 & 0.60 \\
\hline Adjusted $\mathbf{R}^{2}$ & & 0.45 & & 0.56 & 0.60 & 0.79 & 0.59 & 0.56 \\
\hline
\end{tabular}

Notes: $*, * *, * *$ denote significance at $10 \%, 5 \%$ and $1 \%$, respectively. A significant $G O V$ coefficient suggests governance quality is an important determinant of bank performance in Egypt. See Table 2 for variable definitions.

Table 5 presents the results of significance testing for Model 1 and related analyses. Model 1 is highly significant at the .01 level and has a high explanatory power $\left(\mathrm{R}^{2}\right.$ is 0.48 and adjusted $\left.\mathrm{R}^{2} 0.45\right)$. As expectations, the coefficient on $G O V$ is marginally significantly positive. $P E R F$ is also significantly positively associated with $C A P A D Q, F E E$ and $M E F F$ and significantly negatively associated with $L L P$ and $L I Q$.

Model 1 (a): PERF and governance components

Aside from analyzing the relation between PERF and GOV, we analyze the relation between PERF and governance components in a separate model, labeled Model 1 (a). The tested model is highly significant at the .01 level and has an $\mathrm{R}^{2}$ of 0.60 and adjusted $\mathrm{R}^{2} 0.56$. Contrary to expectations, COMP is marginally significantly negative and $\mathrm{C} 1$ is highly significantly negative. But, as expected, FOR has a significantly positive relation to PERF. Thus results suggest that bank performance over the period 2000-2009 was inversely associated with board composition and ownership concentration, but positively associated with foreign ownership. The effect sizes of C1 and FOR are much higher than that of COMP.

To identify whether the significant results of $\mathrm{H}_{1}$ hold for banks at all governance levels, we repeat Model 1 (a) for each of the two governance categories: high and low governance groups. Results suggest that in well-governed banks and in poorly-governed banks alike, performance is a function of foreign ownership, ownership concentration and the separation of CEO/Chairman positions. We do not tabulate the results of the low/high governance analysis for sake of brevity. 
Model 1 (b) - (e): Performance dimensions and governance components

As additional analysis, we analyze the impact of individual bank governance components (BSIZE, COMP, C1, FOR, $I N S T$, and $D U A L$ ) on each of the four performance dimensions explored in this study: ROA, DKMTSH, OPEFF, and $P R O D$. The objective is to explore the governance component that drives specific performance dimensions. It must be noted that analyzing the effects of individual governance components on these components is ex-post and no theory was created regarding the investigated relations and therefore no predictions are made for the directions of the signs. To test these effects, we repeat the empirical testing of Model 1 in four different OLS regression models titled Model 1 (b) through (e), after replacing the dependent variable PERF in each model with one of the performance dimensions.

The results of regressing each performance dimension on governance components are shown in Table 5 under the "Ex-Post Analysis" title. The F-statistics on all four models (b) through (e) are significant at the .01 level and have high explanatory powers. $R^{2}$ for models (b) through (e) are $0.64,0.80,0.62$, and 0.60 , respectively and adjusted $\mathrm{R}^{2}$ for the models are $0.60,0.79,0.59$, and 0.56 , respectively.

The results of empirical testing of Model 1(b) indicate that $R O A$ (financial performance) is marginally significantly related to board composition. Further, ROA is significantly positively related to CAPADQ, FEE, and SIZE and is significantly negatively related to $L L P$ and $L I Q$. The results of empirical testing of Model 1 (c) indicate that DMKTSH (deposit market share) is insignificantly positively affected by duality, institutional ownership and board composition, but significantly positively related to ownership concentration, and significantly negatively related to foreign ownership and board size.

The results of empirical testing of Model 1 (d) indicate that $O P E F F$ is insignificantly negatively affected by board size, and board duality, but insignificantly positively related to board composition, foreign ownership, ownership concentration and institutional ownership. OPEFF is significantly positively related to $L L P, L I Q, G D P G R O$, and CRISIS, and is significantly negatively related to FEE, SIZE, and YearCode.

The results of empirical testing of Model 1 (e) indicate that $P R O D$ is significantly positively affected by foreign and institutional ownership, and significantly negatively affected by board size and board composition and ownership concentration. PROD is significantly positively related to CAPADQ, FEE, MEFF, and SIZE and is significantly negatively related to $L I Q$.

The overall conclusion from testing Model 1 (a) through (e) is that governance components have strong effects on all performance dimensions. Foreign ownership and ownership concentration have the strongest effects on performance dimensions, especially customer-related performance, and employee productivity. Institutional ownership is influential in explaining the variations in employee productivity. Board composition explains variations in financial performance and learning \& growth process. Board size has limited explanatory power on customer-related performance and learning \& growth.

\subsection{Research Limitations}

In conducting the analysis, we face a number of empirical challenges. The first is that the governance data, especially those related to director independence, ownership concentration, and foreign ownership, are not easily accessible or publicly available from more than one source. Only one source, KOMPASS EGYPT, offers governance data, and this prevents ensuring the accuracy of data. Additionally, the period studied in this paper extends back to 1998 in some cases. The availability and accuracy of governance, and accounting data at that time may not be accurate because the stock market was still in its rebirth stages. Also, the year 2008 was an unusual year of global economic crisis. Although controls have been incorporated in the analysis to prevent any effects of this crisis on the analysis, still if any omitted effects of the crisis affected the models, results may have been affected.

\section{Conclusion and Recommendations}

The purpose of this study is to test the association between corporate governance and bank performance in a sample consisting of banks operating in Egypt during the period from year 2000 - 2009. The empirical results show that governance quality index has marginal significant positive impact on bank performance. This finding is consistent with many studies (for example; Williams and Nguyen, 2005; Choi and Hassan, 2005; Laeven and Levine, 2009). Furthermore, the effect of governance index components on performance components is examined separately. Evidence shows that performance is a function of some of the individual governance quality components.

In particular, evidence shows that board composition proxied by proportion of non-executive directors has marginally significant negative impact on bank performance. This is consistent with studies that find no significant 
relationship between presence of outsiders and bank performance (Pi and Timme, 1993; Staikouras et al., 2007; and Adams and Mehran, 2012). However, it contrasts with views emphasizing presence of independent directors on bank board for their ability to mitigate the agency problem and enhance performance due to their diversified experiences and qualification (e.g. Subrahmanyam et al., 1997; and Belkhir, 2009). Further analysis shows that increasing number of independent directors on bank board will have adverse effect on learning and growth and financial performance perspectives. This could be interpreted as bank executives have more access to specific-bank information, knowledge, and more communication with bank employees and aware of their problems, which enable them to stimulate, encourage and enhance employees' performance and productivity through professional trainings, orientations, and compensation schemes.

In spite of the strong argument that the positions of CEO and Chairman should be separated in the Egyptian banks to reduce agency cost and mitigate managerial entrenchment, the empirical evidence shows that the relation between $\mathrm{CEO} /$ Chairman duality and bank performance is insignificant. Further, when analyzing the components of the performance index separately, we find that duality has no impact on all performance dimensions. Similarly and aside from banking firms, this result agrees with Brickley et al. (1997) who argue that the optimal leadership structure varies across firms and according to the characteristics of the firm. However, this finding do not find support for the results of Pi and Timme (1993) who report a negative relationship between bank performance and duality due to the increase in the agency conflicts between owners and management.

Foreign ownership is found to be associated with high performance, as bank performance is significantly positively related to foreign ownership. Foreign ownership has high significant impact on bank performance, specifically on customer-related performance and employee productivity. This gives support to the results of many studies such as Micco et al. (2004), Berger et al. (2005), Choi and Hassan (2005).

In addition, ownership concentration adversely affects the Egyptian banks performance, as evidence indicates that ownership concentration is highly significant and negatively associated with bank performance. The findings support many scholars who are opponents of concentration of ownership and argue that concentration leads to expropriation of minorities and poor performance, for example Gomes and Novaes (2005), Burkart et al. (1997), Laeven and Levine (2009). However, this result is against the view of ownership concentration is more effective and enhances monitoring and governance, for example; Shehzad et al. (2010) and Iannotta et al. (2007). Thus, ownership concentration and foreign ownership are influential determinants of customer-related performance, and the learning and growth as performance dimensions.

Evidence also shows that institutional ownership is a marginal determinant of employee productivity. Finally, board size is found to be insignificant determinant for bank performance; however, small board size is a significant determinant for better customer-related and improved learning \& growth. This result is against the studies that argue that large boards have positive impact on bank performance, for example, Subrahmanyam et al. (1997), Adams and Mehran (2005), Andres and Vallelado (2008), and Belkhir (2009).

Moreover, empirical evidence shows that credit risk, liquidity, capital adequacy, non-interest income, and managerial efficiency are significant determinants for bank performance. These results are consistent with the findings of Berger et al. (1995) and Goddard et al. (2004) who argue that capital adequacy has a positive impact on bank performance. Naceur and Kandil (2009) also reported that higher capital-to-assets ratios and increase in management efficiency lead to improvement in the performance of the banking sector in Egypt.

The results of the analyses suggest that much research effort is needed in this area. One promising area for future research and regulation is how future-banking regulations in Egypt can aim at improving these two dimensions, perhaps by including research-based provisions in future banking laws that provide incentives for banks exhibiting continuous improvements in operating efficiency, organizational learning, employee empowerment, streamlined business processes, community relations, and timely adoption of modern IT systems.

\section{Acknowledgments}

The authors would like to thank the editor and the two anonymous referrers for their helpful comments and suggestions.

\section{References}

Abbott, L., Parker, S., Peters G.F. \& Aghunandan, K R. (2003). An empirical investigation of audit fees, non-audit fees and audit committees. Contemporary Accounting Research, 20 (2), 215-234. http://dx.doi.org/ 10.1506/8YP9-P27G-5NW5-DJKK. 
Adams, R., \& Mehran, H. (2005). Corporate performance, board structure and its determinants in the banking industry. Working Paper, University of Queens land Business School Federal Reserve Bank of New York. http://dx.doi.org/10.1596/1813-9450-3532.

Adams, R. B., \& Mehran, H. (2012). Bank board structure and performance: Evidence for large bank holding companies. Journal of Financial Intermediation, 21(2), 243-267. http://dx.doi.org/10.1016/j.jfi.2011.09.002.

Andres, P., \& Vallelado, E. (2008). Corporate governance in banking: The role of board of directors. Journal of Banking and Finance, 32, 2570-2580. http://dx.doi.org/10.1016/j.jbankfin.2008.05.008.

Athanasoglou, P.P., Brissimis, S.N., \& Delis, M.D. (2008). Bank-specific, industry-specific and macroeconomic determinants of bank profitability. Journal of International Financial Markets Institutions and Money, 18 (2), 121-136. http://dx.doi.org/10.1016/j.intfin.2006.07.001.

Barajas, A., Steiner, R., \& Salazar, N. (1999). Interest spreads in banking in Colombia, 1974-96. International Monetary Fund, IMF Staff Papers, 46 (2).

Basel Committee on Banking Supervision. (2006). Enhancing corporate governance for banking organizations. Bank for International Settlements, Switzerland.

Beasley, M. S. (1996). An empirical analysis of the relation between the board of director composition and financial statement fraud. Accounting Review, 71 (4), 443-466.

Belkhir, M. (2009). Board of directors' size and performance in the banking industry, International Journal of Managerial Finance, 5 (2), 201-221. http://dx.doi.org/10.1108/17439130910947903.

Berger, A.N., Clarke, G.R.G., Cull, R., Klapper, L., \& Udell, G.F. (2005). Corporate governance and bank performance: A joint analysis of the static, selection, and dynamic effects of domestic, foreign, and state ownership. Journal of Banking \& Finance, 29, 2179-2221. http://dx.doi.org/10.1016/j.jbankfin.2005.03.013.

Berger, A.N., Herring, R.J., \& Szego, G.P. (1995). The role of capital in financial institutions. Journal of Banking and Finance, 19, 257-276. http://dx.doi.org/10.1016/0378-4266(95)00002-X.

Berle, A. \& Means, G. (1933). The Modern Corporation and Private Property. MacMillan, New York.

Booth, J.R., Cornett, M.M., \& Tehranian, H. (2002). Boards of directors, regulation and ownership. Journal of Banking and Finance, 26, 1973-1996. http://dx.doi.org/10.1016/S0378-4266(01)00181-9.

Brewer, P., Davis, S., \& Albright, T. (2004). Security regional bank: implementing a Balanced Scorecard using the business modeling approach. Journal of Corporate Accounting and Finance, 15 (5), 73-83. http://dx.doi.org/10.1002/jcaf.20041.

Brickley, J.A., Coles J.L., \& Jarrell, G. (1997). Leadership structure: Separating the CEO and Chairman of the board. Journal of Corporate Finance, 3, 189-220. http://dx.doi.org/10.1016/S0929-1199(96)00013-2.

Burkart, M., Gromb, D., \& Panunzi, F. (1997). Large shareholders, monitoring, and the value of the firm. Quarterly Journal of Economics, 112, 693-728. http://dx.doi.org/10.1162/003355397555325.

C.B.E. (2007). Annual Report of year 2006/2007, Central Bank of Egypt, Cairo.

Choi, S., \& Iftekhar, H. (2005). Ownership, governance, and bank performance: Korean experience. Financial Markets, Institutions \& Instruments, 14 (4), 215-242. http://dx.doi.org/10.1111/j.0963-8008.2005.00104.x

Chow, C. \& Wong-Borne, A. (1987). Voluntary financial disclosure by Mexican corporations. The Accounting Review, 3, 533-41.

Claessens, S., Djankov, S., Fan, J., \& Lang, L. (2002). Disentangling the incentive and entrenchment effects of large shareholdings. Journal of Finance, 57, 2741-71. http://dx.doi.org/10.1111/1540-6261.00511.

Coles, J., Daniel, N., \& Naveen, L. (2008). Boards: Does on size fit all? Journal of Financial Economics, 87 (2), 329-356. http://dx.doi.org/10.1016/j.jfineco.2006.08.008.

Cornett, M.M., Marcus, A.J., Saunders, A., \& Tehranian, H. (2007). The impact of institutional ownership on corporate operating performance. Journal of Banking and Finance, 31(6), 1771-1794. http://dx.doi.org/10.1016/j.jbankfin.2006.08.006.

Defond, M. L., \& Hung, M. (2004). Investor protection and corporate governance: Evidence from worldwide CEO turnover, Journal of Accounting Research, 42 (2), 269-312. http://dx.doi.org/10.1111/j.1475-679X.2004.00138.x. 
Demirgüç-Kunt, A., Laeven, L., \& Levine, R. (2004). regulations and the cost of financial intermediation. Journal of Money Credit and Banking, 36 (3), 593-622. http://dx.doi.org/10.1353/mcb.2004.0045.

Elyasiani, E., \& Jia, J.J. (2008). Institutional ownership stability and BHC performance. Journal of Banking and Finance, 32, 1767-1781. http://dx.doi.org/10.1016/j.jbankfin.2007.12.010.

Fama, E.F., \& Jensen, M.C. (1983). Separation of ownership and control. Journal of Law and Economics, 26, 301-325. http://dx.doi.org/10.1086/467037.

Goddard, J., Molyneux, P., \& Wilson, J. (2004). The profitability of European banks: A cross-sectional and dynamic panel analysis. The Manchester School, 72 (3), 363-381. http://dx.doi.org/10.1111/j.1467-9957.2004.00397.x.

Gomes, A.R., \& Novaes, W. (2005). Sharing of control as a corporate governance mechanism. PIER Working Paper No. 01-029.

Gompers, P. J., \& Metrick, A. (2003). Corporate governance and equity prices. Quarterly Journal of Economics, 118 (1), 107-155. http://dx.doi.org/10.1162/00335530360535162.

Goyal, Vidhan K., \& Park, Chul W. (2002). Board leadership structure and CEO turnover. Journal of Corporate Finance, 8 (1), 49-66. http://dx.doi.org/10.1016/S0929-1199(01)00028-1.

Iannotta, G., Nocera, G., \& Sironi, A. (2007). Ownership structure, risk and performance in the European banking industry, Journal of Banking Finance, 31, 2127-2149. http://dx.doi.org/10.1016/j.jbankfin.2006.07.013.

International Monetary Fund-IMF. (2002). Essays on Trade and Finance. World Economic Outlook, 65-107.

Jensen, M. (1993). The modern industrial revolution, exit, and the failure of internal control systems. Journal of Finance, 48, 831-880. http://dx.doi.org/10.1111/j.1540-6261.1993.tb04022.x.

Kaplan, R., \& Norton, D. (1992). The Balanced Scorecard measures that drive performance. Harvard Business Review, January-February 1992.

Kwan, S.H. (2004). Risk and return of publicly held versus privately owned banks. Federal Reserve Bank of New York Economic Policy Review, 10, 97-107.

La Porta, R., Lopez-de-Silanes, F., \& Shleifer, A. (1997). Legal determinants of external finance. Journal of Finance, 52, 1131-50. http://dx.doi.org/10.1111/j.1540-6261.1997.tb02727.x.

Laeven, L.A., \& Levine, R. (2009). Bank governance, regulation and risk taking. Journal of Financial Economics, 93, 259-275. http://dx.doi.org/10.1016/j.jfineco.2008.09.003.

Levine, R. (2004). The corporate governance of banks: A concise discussion of concepts and issues. World Bank Policy Research, Working Paper Series No. 3404.

Linck, JS., Netter, JM., \& Yang T. (2008). The determinants of board structure. Journal of Financial Economics, 87 (2), 308-328. http://dx.doi.org/10.1016/j.jfineco.2007.03.004.

Macey, J., \& O'Hara, M. (2003). The corporate governance of banks. Federal Reserve Bank of New York Economic Policy Review, 9 (1), 91-107.

Micco, A., Panizza, U., \& Yanez, M. (2004). Bank ownership and performance. Inter-American Development Bank. Working Paper No. 518.

Naceur, S. B., \& Kandil, M. (2009). The impact of capital requirements on banks' cost of intermediation and performance: The case of Egypt. Journal of Economics and Business, 61 (1), 70-89. http://dx.doi.org/10.1016/j.jeconbus.2007.12.001

Pathan, S., \& Faff, R. (2013). Does board structure in banks really affect their performance?. Journal of Banking \& Finance, 37(5), 1573-1589. http://dx.doi.org/10.1016/j.jbankfin.2012.12.016

Pi, L., \& Timme, S.G. (1993). Corporate control and bank efficiency. Journal of Banking and Finance, 20 (2), 515-530. http://dx.doi.org/10.1016/0378-4266(93)90050-N.

Salzman, J. (2003). Methodological choices encountered in the construction of composite indices of economics and social well-being. Centre for the Study of Living Standards Report 2004-2005.

Shehzad C.T, De Haan, J., \& Scholtens, B. (2010). The impact of bank ownership concentration on impaired loans and capital adequacy. Journal of Banking and Finance, 34 (2), 399-408. http://dx.doi.org/10.1016/j.jbankfin.2009.08.007. 
Shleifer, A., \& Vishny, R.W. (1986). Large shareholders and corporate control. Journal of Political Economy, 94, 461-488. http://dx.doi.org/10.1086/261385.

Staikouras P., Staikouras, C., \& Agoraki, M. (2007). The effect of board size and composition on European bank performance. European Journal of Law \& Economics, 23: 1-27. http://dx.doi.org/10.1007/s10657-007-9001-2.

Subrahmanyam, V., Rangan, N., \& Rosenstein, S. (1997). The role of outside directors in bank acquisitions. Journal of Financial Management, 26 (3): 23-36. http://dx.doi.org/10.2307/3666211.

Vafeas, N. (1999). Board meeting frequency and firm performance. Journal of Financial Economics, 53, 113-142. http://dx.doi.org/10.1016/S0304-405X(99)00018-5.

Wang, W. (2005). An evaluation of the Balanced Scorecard in equity valuation: The case of exchange ratio in the Mergers and acquisitions of Taiwan's financial industry. Journal of Intellectual Capital, 6 (2), 206-221. http://dx.doi.org/10.1108/14691930510592807.

Williams, J., \& Nguyen, N. (2005). Financial liberalization, crisis, and restructuring: A comparative study of bank performance and bank governance in south East Asia. Journal of Banking and Finance, 29, 2119-2154. http://dx.doi.org/10.1016/j.jbankfin.2005.03.011.

Zemzem, A., \& Kacem, O. (2014). Risk Management, Board Characteristics and Performance in the Tunisian Lending Institutions. International Journal of Finance \& Banking Studies (ISSN: 2147-4486), 3(1), 186-200.

\section{Notes}

Note 1. Adams and Mehran (2005) compare the board size of U.S. BHCs with non-financial firms and find that the mean board size is 18.2 for BHCs while it is 12.1 for non-financial firms.

Note 2. The average bank board size reported in these studies range between 16 to maximum 19 directors, this is higher than the average board size (12 members) reported for non-financial firms (e.g. Vafeas, 1999).

Note 3. KOMPASS EGYPT is owned by Fiani \& Partners, a firm that specializes in providing financial information products primarily directed to the investment and credit community. It issues the Financial Yearbook annually in print edition. The Yearbook has two types of financial listings: full financial statements and highlights for the current year.

Note 4. Data validation of the Financial Yearbook financial information has been conducted for a sample of 20 banks for the period 2006-2007 by comparing their financial information with data included in the financial statements issued by the firms. However, we could only validate 5 firms for the period 1997-1998 due to unavailability of firm financial statements. Validation showed that financial statement data in the Yearbook is highly accurate.

Note 5. All measures were hand collected from the KOMPASS EGYPT directory of Egyptian firms' economic information and sample firms' financial statements, including board information.

Note 6. Reliability tests were conducted on the components and Chronbach alpha measured 65 .

Note 7. Reliability tests were conducted on the components and Chronbach alpha measured .71. 